\title{
UCRL-JRNL-213786
}

LAW RENCE LIVERMORE N A T IO N A L LABORATORY

Fourier Transform Infrared Spectroscopic Analysis Of Plastic Capsule Materials Exposed To Deuterium-Tritium (DT) Gas

J. R. Schoonover, W. P. Steckle, Jr., N. Elliot, P. S. Ebey, A. Nobile, A. Nikroo, R. C. Cook, S. A. Letts

July 20, 2005

Fusion Science and Technology 
This document was prepared as an account of work sponsored by an agency of the United States Government. Neither the United States Government nor the University of California nor any of their employees, makes any warranty, express or implied, or assumes any legal liability or responsibility for the accuracy, completeness, or usefulness of any information, apparatus, product, or process disclosed, or represents that its use would not infringe privately owned rights. Reference herein to any specific commercial product, process, or service by trade name, trademark, manufacturer, or otherwise, does not necessarily constitute or imply its endorsement, recommendation, or favoring by the United States Government or the University of California. The views and opinions of authors expressed herein do not necessarily state or reflect those of the United States Government or the University of California, and shall not be used for advertising or product endorsement purposes. 


\title{
FOURIER TRANSFORM INFRARED SPECTROSCOPIC
}

\section{ANALYSIS OF PLASTIC CAPSULE MATERIALS EXPOSED TO DEUTERIUM-TRITIUM (DT) GAS}

\author{
Jon R. Schoonover, Warren P. Steckle, Jr., Norman Elliot, \\ Peter S. Ebey, Arthur Nobile \\ Los Alamos National Laboratory, Los Alamos, New Mexico 87544
}

\author{
Abbas Nikroo \\ General Atomics, San Diego, CA 92186 \\ Robert C. Cook, Stephan A. Letts \\ Lawrence Livermore National Laboratory, Livermore, California 94550
}




\begin{abstract}
Planar samples of varying thicknesses of both $\mathrm{CH}$ and $C D$ glow discharge polymer have been measured with Fourier transform infrared (FTIR) spectroscopy before and after exposure to deuterium-tritium (DT) gas at elevated temperature and pressure. Planar samples of polyimide films made from both hydrogenated and deuterated precursors have also been examined by FTIR before and after DT exposure. The post-exposure FTIR spectra demonstrated no measurable exchange of hydrogen with deuterium or tritium for either polymer. Evidence for oxidation of the glow discharge polymer due to atmospheric oxygen was the only chemical change indicated by the FTIR data.
\end{abstract}

KEYWORDS: FTIR, isotopic substitution 


\section{INTRODUCTION}

Targets for inertial fusion ignition experiments at the National Ignition Facility will contain deuterium-tritium (D-T) fuel. ${ }^{1}$ The purpose of the current set of experiments was to expose samples of relevant polymeric materials that may be used in these capsules to D-T gas at elevated temperature and pressure to investigate the effects of D-T on the materials. Transmission infrared spectroscopy provides one of the best methods to study any changes in polymeric materials exposed D-T gas. In transmission mode, Fourier transform infrared (FTIR) studies provide the opportunity to gauge isotopic substitution by spectral shifts due to a mass effect, the relative amount of any substitution, and any additional chemical changes. In this set of experiments, samples of both normal (hydrogenated) glow discharge polymer, $\mathrm{CH}$, and its deuterated analog, $\mathrm{CD},{ }^{2}$ of varying thicknesses were examined as planar samples in the transmission mode before and after exposure to D-T. Similarly, vapor deposited hydrogenated polyimide and deuterated polyimide ${ }^{3}$ of varying thicknesses were examined.

Generally "DT" is an isotopic mixture of $\mathrm{D}_{2}, \mathrm{DT}$, and $\mathrm{T}_{2}$ in a 1:2:1 ratio.

Although pure DT can be prepared, ${ }^{4}$ it is rapidly converted to the equilibrium isotopic mixture due to the decay of the tritium

$$
{ }_{1}^{3} \mathrm{H} \rightarrow{ }_{2}^{3} \mathrm{He}+{ }_{-1}^{0} \beta
$$


The energetic ${ }_{-1}^{0} \beta$ then cleaves molecular species to produce radicals that result in the scrambling of the isotopic mix, e.g.:

$$
\begin{aligned}
& { }_{-1}^{0} \beta+\mathrm{DT} \rightarrow \mathrm{D}+\mathrm{T} \\
& \mathrm{D}+\mathrm{DT} \rightarrow \mathrm{D}_{2}+\mathrm{T}
\end{aligned}
$$

It is this decay and the energetic species that it produces that is the source of energy for isotopic exchange and chain rearrangement often seen in polymeric materials.

Isotopic exchange has been observed in different organic polymers, but primarily with pure tritium gas or tritiated water. Calculations demonstrate that isotopic exchange occurs much faster in an atmosphere of pure $\mathrm{T}_{2}$ as compared to D-T. ${ }^{5}$ Tritium exchange for hydrogen atoms of carboxylic acid and alcohol functional groups, but not with $\mathrm{C}-\mathrm{H}$ groups, have been observed with tritiated water. ${ }^{6}$ Two potential exchange mechanisms could occur with DT in organic polymers such as polyethylene. ${ }^{7}$ The Wilzbach heterogeneous exchange assumes that $\beta$ radiation produces a radical species in the polymer that reacts with molecular DT (or $\mathrm{D}_{2}$ or $\mathrm{T}_{2}$ ). An example is shown below:

$$
\begin{array}{r}
\mathrm{RH}+\beta \rightarrow \mathrm{R}+\mathrm{H} \\
\mathrm{R}+\mathrm{DT} \rightarrow \mathrm{RD}+\mathrm{T}
\end{array}
$$

The other relevant mechanism occurs with a reaction to produce an activated $\mathrm{T}$ (or $\mathrm{D}$ ) radical, which reacts with the polymer: 


$$
\begin{aligned}
& { }_{-1}^{0} \beta+\mathrm{DT} \rightarrow \mathrm{D}+\mathrm{T} \\
& \mathrm{D}+\mathrm{RH} \rightarrow \mathrm{RD}+\mathrm{H}
\end{aligned}
$$

Other possible reactions for organic polymers initiated by radical mechanisms include oxidation, which would produce functional groups with oxygen atoms, and polymer cross-linking, which would be manifest as changes in the $\mathrm{C}-\mathrm{H}$ and $\mathrm{C}-\mathrm{C}$ stretching regions of the infrared spectra. For example, exposure of polyethylene to 1 atmosphere of tritium gas at ambient temperature for 108 days indicated formation of cross-links and an increase in stiffness, presumably via radiation induced chain scission followed by crosslinking reactions. ${ }^{8}$ FTIR spectra also suggested some tritium exchange in this study. ${ }^{8}$

Polyimide represents a robust polymer with numerous applications. ${ }^{9}$ Unlike glow discharge polymer, all C-H linkages are aromatic. It has been reported that Kapton polyimide, chemically identical to the vapor deposited polyimide used in this study, shows little change with exposure to tritium at 1 atmosphere for 108 days at ambient temperature. $^{8}$

\section{EXPERIMENTAL}

Planar, thin film samples of vapor deposited polyimide and the glow discharge polymer were used in this study. The 20 samples varied in thickness from 7.2 to $60 \mu \mathrm{m}$. Samples of H-PI and D-PI were prepared from pyromellitic dianhydride (PMDA) and 4,4'-oxydianiline (ODA) or their fully deuterated analogs. Samples of either CH or CD 
were prepared by standard techniques ${ }^{10}$ from $\mathrm{CH}_{4}$ and $\mathrm{H}_{2}$ or $\mathrm{CD}_{4}$ and $\mathrm{D}_{2}$. The FTIR spectra of the deuterated samples do indicate a small level of $\mathrm{C}-\mathrm{H}$ bonds.

FTIR spectra were measured in the transmission mode of a Nicolet NicPlan infrared microscope with a liquid nitrogen cooled mercury cadmium telluride (MCT) detector. The infrared source was a Nicolet 730 FTIR spectrometer. This microscope uses redundant aperaturing and a $100 \mu \mathrm{m}$ spot size. Pre-exposure samples were loaded into a sample cell under an inert He atmosphere and the infrared spectra measured upon removal from the glove box. The sample cell consisted of a four position sample holder, two $2 \mathrm{~mm}$ thick $\mathrm{BaF}_{2}$ windows, a brass frame, and an o-ring. The samples were removed from the sample cell and exposed to 340 atmospheres of DT gas at $70^{\circ} \mathrm{C}$ for 48 hours. These are similar to conditions that would be used in a diffusion fill of a plastic capsule for an ignition experiment. The details of the exposure conditions are reported elsewhere in this issue. ${ }^{11}$

\section{RESULTS}

Figure 1 shows a comparison of the FTIR spectra of $\mathrm{CH}$ and $\mathrm{CD}$ glow discharge polymer before exposure with thicknesses of 8.8 and $7.2 \mu \mathrm{m}$, respectively. The spectra of thicker samples (31.4 and $43.8 \mu \mathrm{m}$ ) are shown in Figure 2. The thicker samples show the same spectral features, but with stronger bands. Some of these infrared bands are either outside the linear region of Beer's Law or saturating. Assignments for relevant infrared bands of the $\mathrm{CH}$ and $\mathrm{CD}$ polymers are presented in Table 1. All the spectra of 
these thin films demonstrate interference fringes, with a period related to the sample thickness.

For the $\mathrm{CH}$ polymer the primary bands observed can be assigned to the $\mathrm{C}-\mathrm{H}$ stretches of $-\mathrm{CH}_{3}$ and $-\mathrm{CH}_{2}$ - as well as the bending motions of these groups. The $\mathrm{C}-\mathrm{H}$ stretches are in the 3000 to $2800 \mathrm{~cm}^{-1}$ region. The scissoring mode of the $-\mathrm{CH}_{2}$ - group gives rise to a band near $1460 \mathrm{~cm}^{-1}$ which often overlaps the $-\mathrm{CH}_{3}$ - asymmetric bend. The symmetric $-\mathrm{CH}_{3}$ bend is observed near $1380 \mathrm{~cm}^{-1}$. Weak combination bands are observed in the infrared spectrum along with carbonyl stretches between 1750 and 1700 $\mathrm{cm}^{-1}$ and $\mathrm{C}=\mathrm{C}$ stretches between 1650 and $1600 \mathrm{~cm}^{-1}$.

The vapor deposited polyimide thin films demonstrate infrared features observed in previous polyimide studies. ${ }^{12}$ Figure 3 shows the spectra of $10 \mu \mathrm{m}$ thick H-PI and D-PI films, while a $50 \mu \mathrm{m}$ thick H-PI spectrum is shown in Figure 4. The primary spectral assignments for polyimide and deuterated polyimide are in Table 2. The spectra indicate some unreacted starting material present in the films.

Post-exposure spectra of the $\mathrm{CH}(8.8 \mu \mathrm{m})$ and $\mathrm{CD}(43.8 \mu \mathrm{m})$ polymers are compared to pre-exposure spectra in Figures 5 and 6. Spectral changes for both $\mathrm{CH}$ and CD polymers include growth of a broad band between 3500 and $3200 \mathrm{~cm}^{-1}$, a gain in infrared absorbance at $1708 \mathrm{~cm}^{-1}$, and a new infrared band at $1118 \mathrm{~cm}^{-1}$. No new bands indicative of replacement of $\mathrm{H}$ with $\mathrm{D}$ or $\mathrm{T}$ or replacement of $\mathrm{D}$ with $\mathrm{T}$ in the deuterated samples is seen. 
Post-exposure spectra of polyimide samples show no gross spectral changes.

Figure 7 is a before and after exposure comparison for a $10 \mu \mathrm{m}$ thick sample of H-PI. No isotopic exchange is noted for this or other polyimide samples.

\section{DISCUSSION}

Isotopic substitution from exposure to D-T gas would result in replacement of a C-H bond with $\mathrm{C}-\mathrm{D}$ or $\mathrm{C}-\mathrm{T}$, or a $\mathrm{C}-\mathrm{D}$ to a $\mathrm{C}-\mathrm{T}$ in the deuterated polymer samples. The shift of the infrared absorbance bands due to these exchanges are significant, and can be predicted based on the change of the reduced mass of the vibrating linkage. ${ }^{13}$ In the case of a $\mathrm{C}-\mathrm{D}$ replacement of a $\mathrm{C}-\mathrm{H}$ linkage, the deuterated samples provide an exact location of the C-D stretches. The most obvious indication of exchange would be the appearance of C-D stretching bands between 2100 and $2200 \mathrm{~cm}^{-1}$ for the exposed $\mathrm{CH}$ samples or around $2300 \mathrm{~cm}^{-1}$ for the H-PI samples.

No post-exposure hydrogenated samples demonstrate measurable C-D absorption bands. Further, the deuterated samples show no evidence of C-T linkages whose vibrational frequency can be estimated to be near $1800 \mathrm{~cm}^{-1}$. The glow discharge polymer shows no changes in absorbance for the $\mathrm{C}=\mathrm{C}$ stretch upon exposure. This functional group would be expected to be the most reactive with D-T gas and the absorbance level remains largely unchanged after exposure. 
For the glow discharge polymer, the only chemical change indicated by the infrared spectra is oxidation with infrared absorbance changes for functional groups such as $-\mathrm{C}=\mathrm{O}$ and $-\mathrm{O}-\mathrm{H}$. Oxidation due to atmospheric oxygen is indicated with increased absorption for $v(\mathrm{OH})$ between 3500 and $3200 \mathrm{~cm}^{-1}, v(\mathrm{C}=\mathrm{O})$ at $1708 \mathrm{~cm}^{-1}$, and $v(\mathrm{C}-\mathrm{C}$ -

$\mathrm{OH})$ at $1118 \mathrm{~cm}^{-1}$. There is no indication of cross-linking reactions in the polymer, which would be manifested as changes in the $v(\mathrm{C}-\mathrm{H})$ bands. For polyimide, no oxidation or cross-linking is indicated.

Thus, we conclude that the approach of diffusion filling of plastic capsules would not lead to measurable isotopic exchange in the plastic and accompanying changes in the infrared transmissive properties of these capsules.

\section{ACKNOWLEDGEMENTS}

This work was performed under the auspices of the U.S. Department of Energy by the Los Alamos National Laboratory under contract No. W-7405-Eng-36 , by General Atomics under contract No. DE-AC03-01SF22266, and by University of California, Lawrence Livermore National Laboratory under contract No. W-7405-Eng-48. 
Table 1. Infrared Bands and Assignments for $\mathrm{CH}$ and $\mathrm{CD}$ Glow Discharge Polymer.

\begin{tabular}{|c|c|c|}
\hline $\mathbf{C H}\left(\mathbf{c m}^{-1}\right)$ & $\mathbf{C D}\left(\mathbf{c m}^{-1}\right)$ & Assignment \\
\hline 2951 & & $v_{\mathrm{a}}(\mathrm{C}-\mathrm{H})-\mathrm{CH}_{3}$ \\
\hline 2928 & $2925 \mathrm{w}$ & $v_{\mathrm{a}}(\mathrm{C}-\mathrm{H})-\mathrm{CH}_{2}-$ \\
\hline 2868 & $2856 \mathrm{w}$ & $v_{\mathrm{s}}(\mathrm{C}-\mathrm{H})-\mathrm{CH}_{2}-,-\mathrm{CH}_{3}$ \\
\hline & 2212 & $v_{\mathrm{a}}(\mathrm{C}-\mathrm{D})-\mathrm{CD}_{2}-,-\mathrm{CD}_{3}$ \\
\hline & 2103 & $v_{\mathrm{s}}(\mathrm{C}-\mathrm{D})-\mathrm{CD}_{2}-$ \\
\hline & 2071 & $v_{\mathrm{s}}(\mathrm{C}-\mathrm{D})-\mathrm{CD}_{3}$ \\
\hline 1740,1707 & 1738,1703 & $v(\mathrm{C}=\mathrm{O})$ \\
\hline 1640,1608 & 1630,1589 & $v(\mathrm{C}=\mathrm{C})$ \\
\hline 1456 & & $-\mathrm{CH}_{2}$ - $\mathrm{scissors}^{-\mathrm{CH}} \mathrm{H}_{3}$ asym HCH bend \\
\hline 1376 & & $-\mathrm{CH}_{3}$ sym $\mathrm{HCH}$ bend \\
\hline & 1084 & $-\mathrm{CD}_{3}$ sym DCD bend \\
\hline & 1055 & $-\mathrm{CD}_{2}$ scissors \\
\hline & & \\
\hline
\end{tabular}


Table 2. Infrared Bands and Assignments for Polyimide Thin Films.

\begin{tabular}{|c|c|c|}
\hline H-PI $\left(\mathrm{cm}^{-1}\right)$ & D-PI $\left(\mathrm{cm}^{-1}\right)$ & Assignments \\
\hline 3489 & 3589 & $v_{\mathrm{a}}(\mathrm{N}-\mathrm{H}), \mathrm{Ar}-\mathrm{NH}_{2}(\mathrm{ODA})$ \\
\hline 3375 & 3376 & $v_{\mathrm{s}}(\mathrm{N}-\mathrm{H}), \mathrm{Ar}-\mathrm{NH}_{2}(\mathrm{ODA})$ \\
\hline $3099,3074,3051$ & & $v(\mathrm{C}-\mathrm{H})$, aromatic ring \\
\hline & $2305,2285,2275$ & $v(C-D)$, aromatic ring \\
\hline 1824 & & $v_{\mathrm{a}}(\mathrm{C}=\mathrm{O})$, anhydride (PMDA) \\
\hline 1778 & 1779 & $\begin{array}{c}v_{\mathrm{s}}(\mathrm{C}=\mathrm{O}) \text {, imide }(\mathrm{PI}), \text { anhydride } \\
(\mathrm{PMDA})\end{array}$ \\
\hline 1726 & 1725 & $v(\mathrm{C}=\mathrm{O})$, imide $(\mathrm{PI})$ \\
\hline 1621 & 1622 & $v_{a}(C=O)$, polyamic acid \\
\hline 1598 & 1572 & $\mathrm{NH}_{2}$ scissors, Ar-NH2 \\
\hline 1502,1455 & 1425,1400 & $v(\mathrm{C}=\mathrm{C})$, aromatic ring \\
\hline 1380 & 1372 & $v(\mathrm{C}-\mathrm{N}-\mathrm{C})$, imide $(\mathrm{PI})$ \\
\hline & 1307 & $v(\mathrm{C}-\mathrm{N}), \mathrm{Ar}-\mathrm{NH}_{2}$ \\
\hline 1243 & 1215 & $v(\mathrm{C}-\mathrm{O}-\mathrm{C})$, imide $\mathrm{Ar}-\mathrm{O}-\mathrm{Ar}$ \\
\hline 1114 & 1116,1093 & $v(\mathrm{C}-\mathrm{N}-\mathrm{C})$, imide \\
\hline
\end{tabular}


Figure Captions:

Figure 1. Transmission FTIR spectra of $\mathrm{CH}$ and $\mathrm{CD}$ polymer films of $8.8 \mu \mathrm{m}$ and $7.2 \mu \mathrm{m}$, respectively.

Figure 2. Transmission FTIR spectra of $\mathrm{CH}$ and $\mathrm{CD}$ polymer films of $31.4 \mu \mathrm{m}$ and 43.8 $\mu \mathrm{m}$, respectively.

Figure 3. Transmission FTIR spectra of $10 \mu \mathrm{m}$ thick H-PI and D-PI polymer films. Figure 4. Transmission FTIR spectra of a $50 \mu \mathrm{m}$ thick H-PI polymer film. Figure5. A comparison of the FTIR spectra of an $8.8 \mu \mathrm{m} \mathrm{CH}$ film before and after exposure to DT gas.

Figure 6. A comparison of the FTIR spectra of a $43.8 \mu \mathrm{m} \mathrm{CD}$ film before and after exposure to DT gas.

Figure 7. A comparison of the FTIR spectra a $10 \mu \mathrm{m}$ H-PI film before and after exposure to DT gas. 
Figure 1
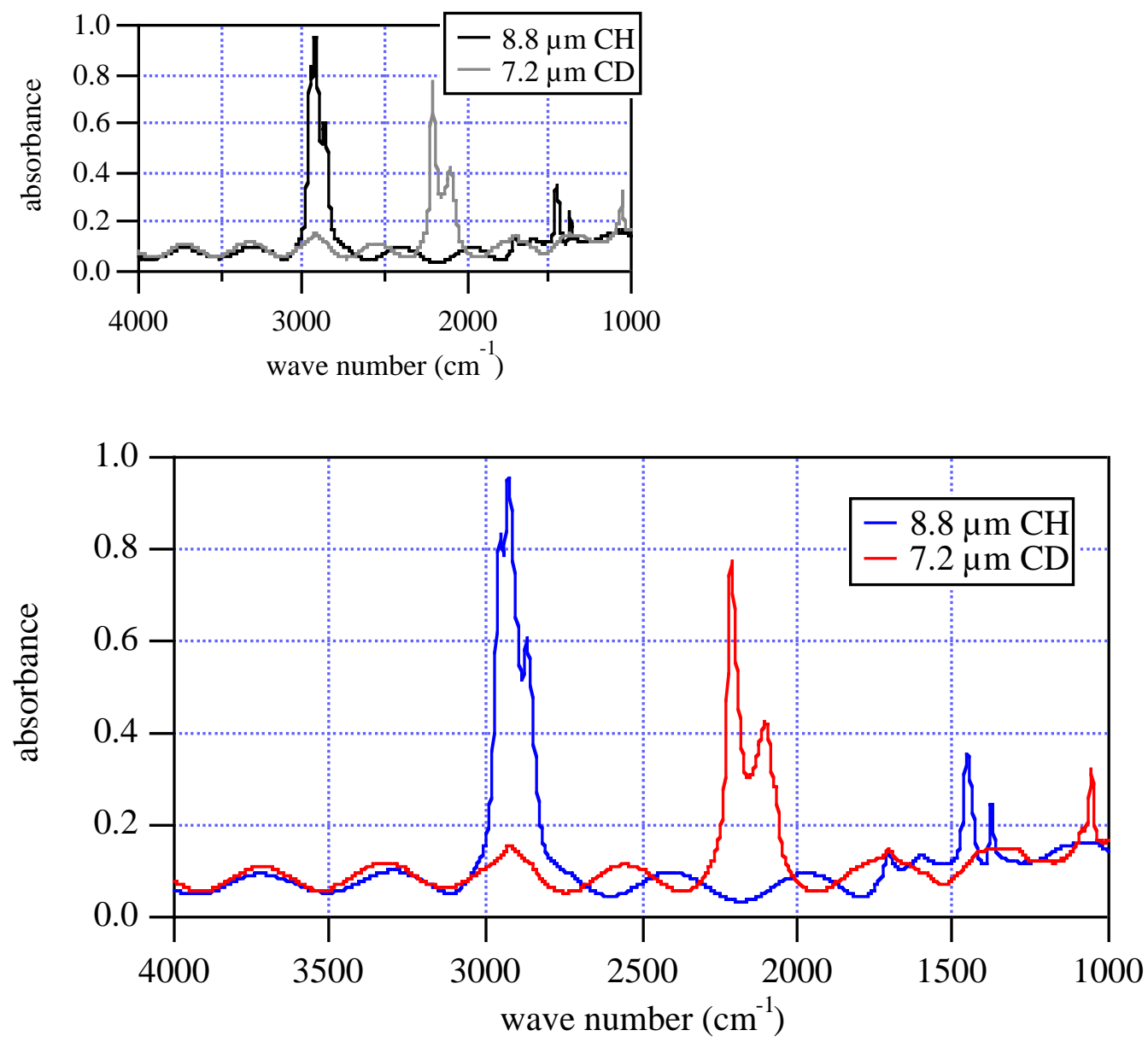
Figure 2
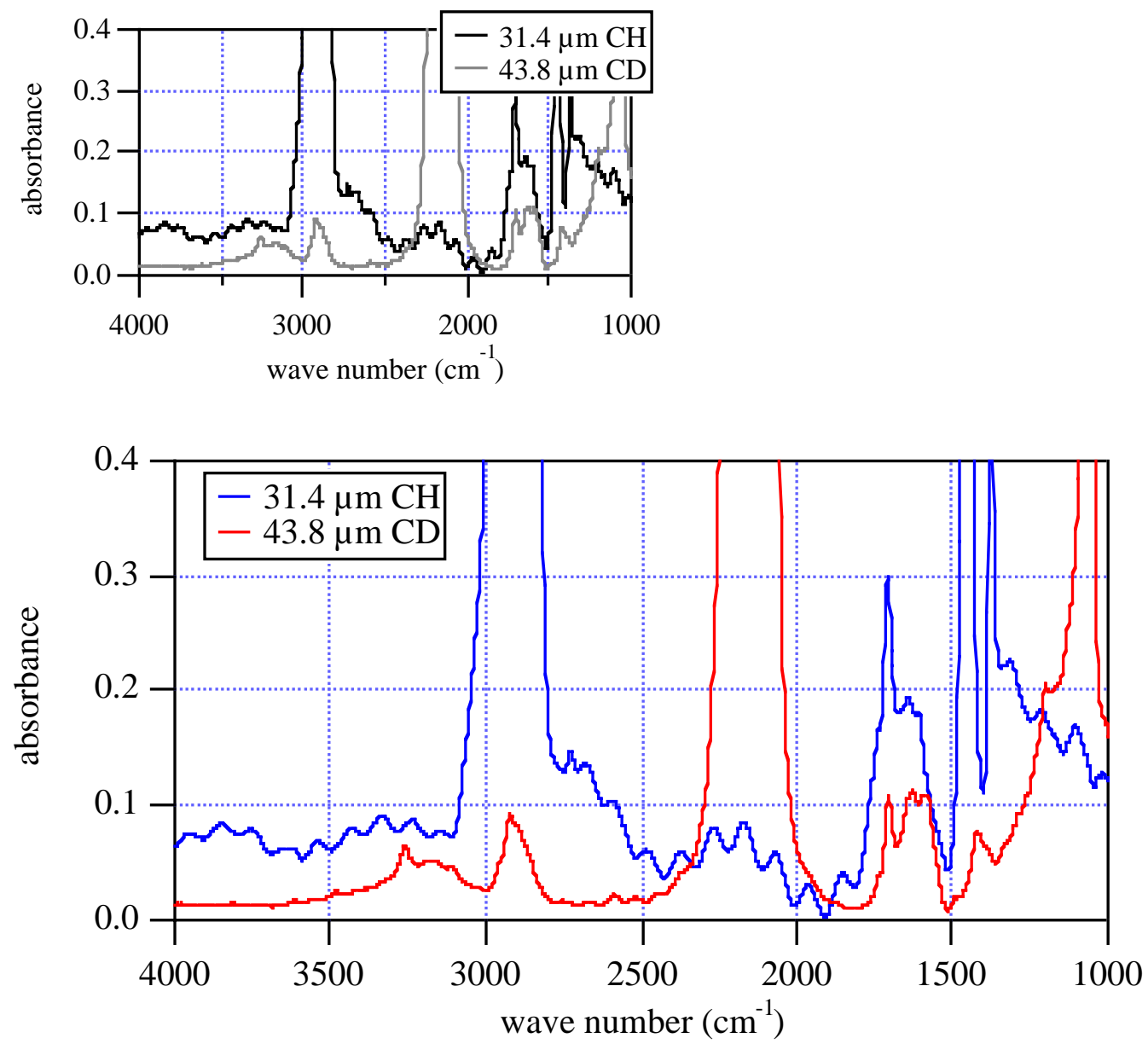
Figure 3
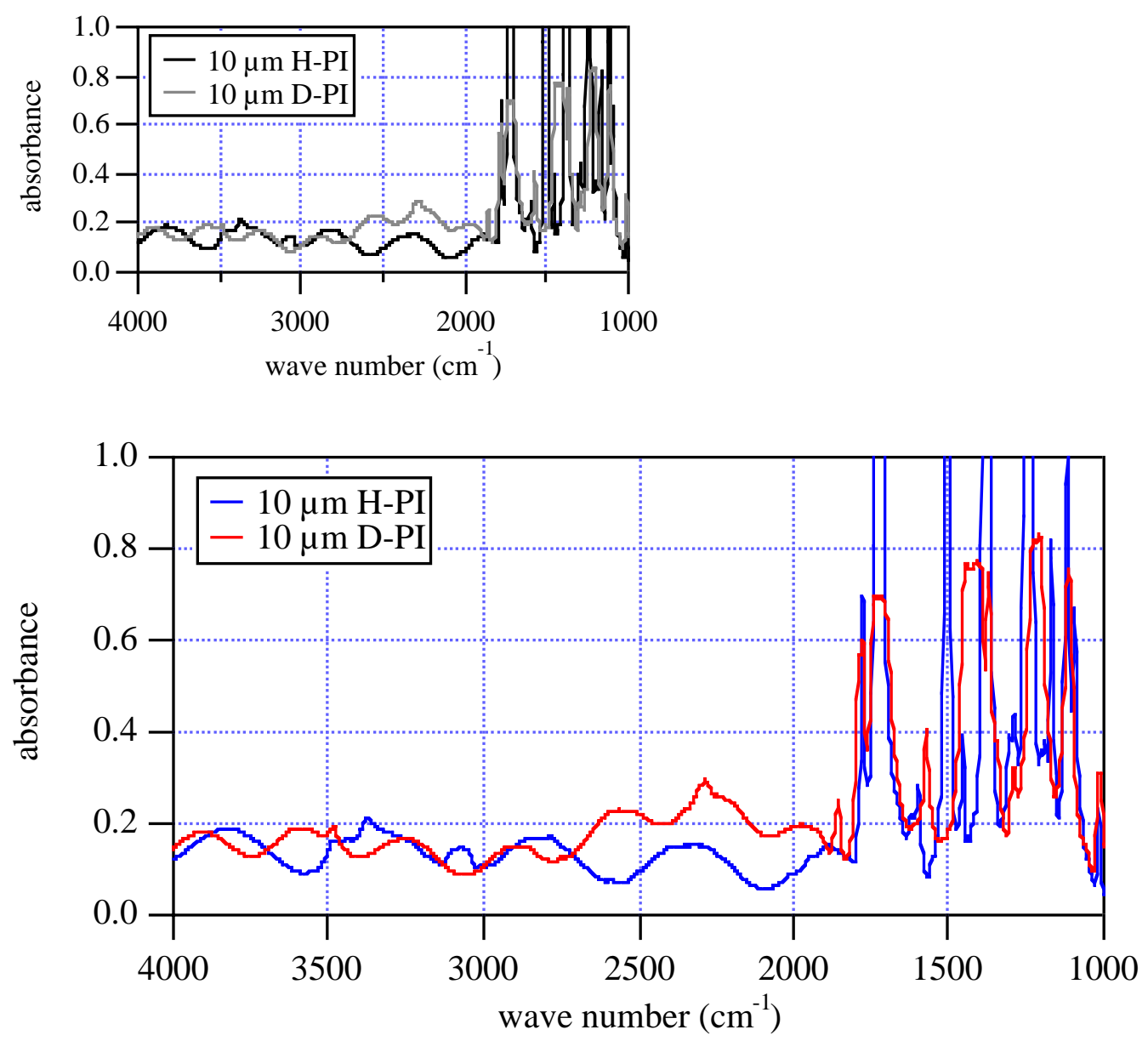
Figure 4
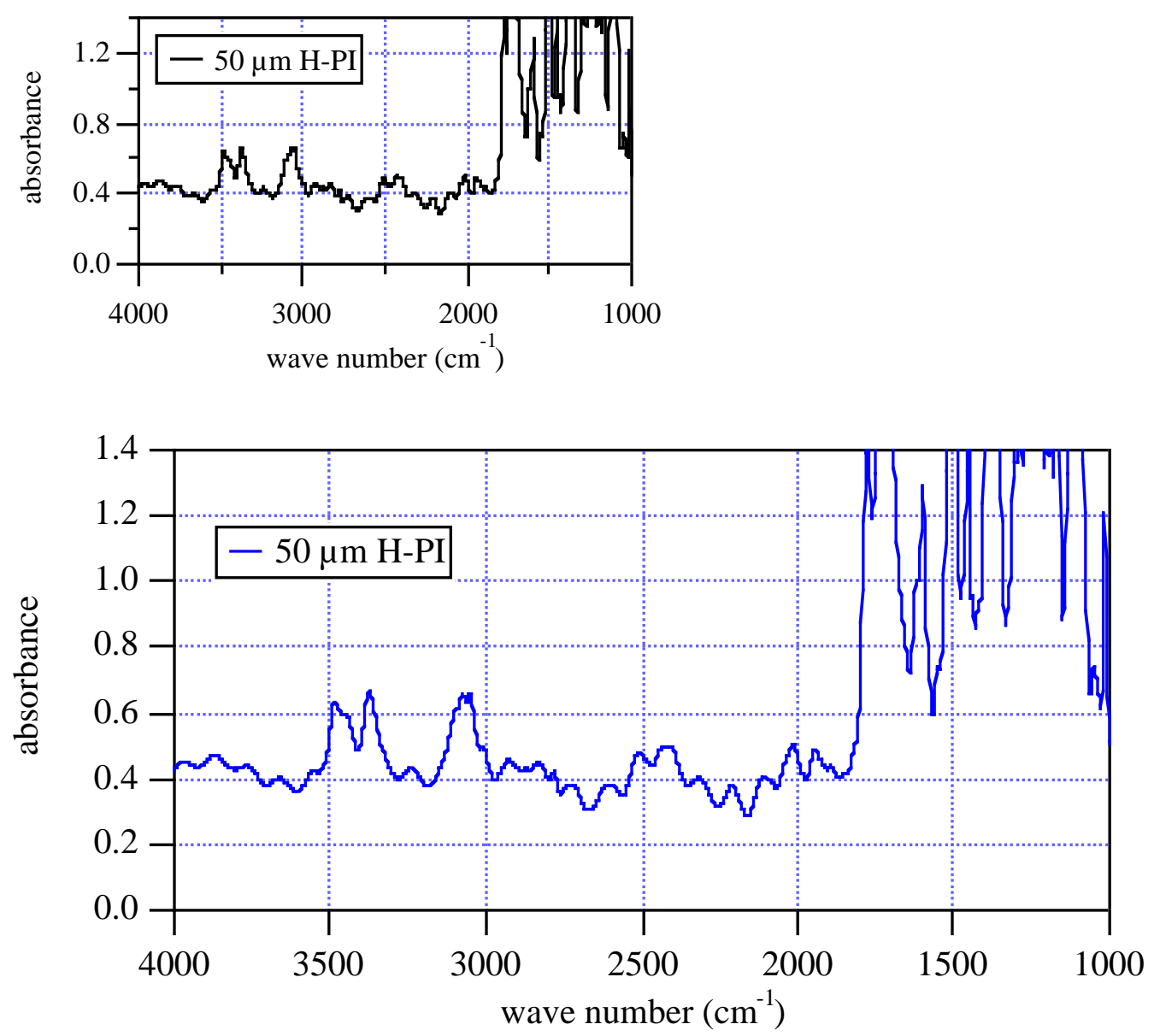
Figure 5
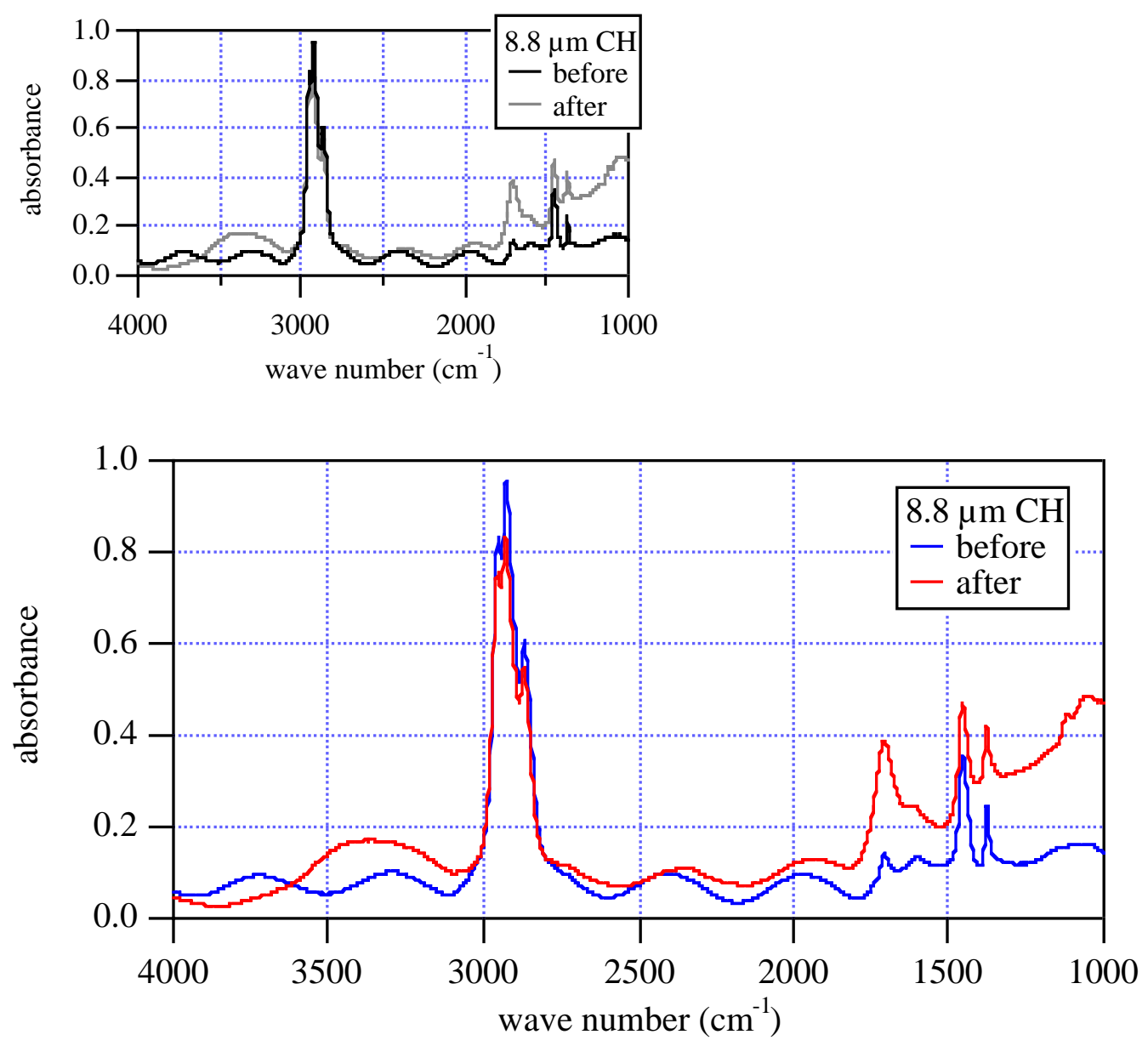
Figure 6
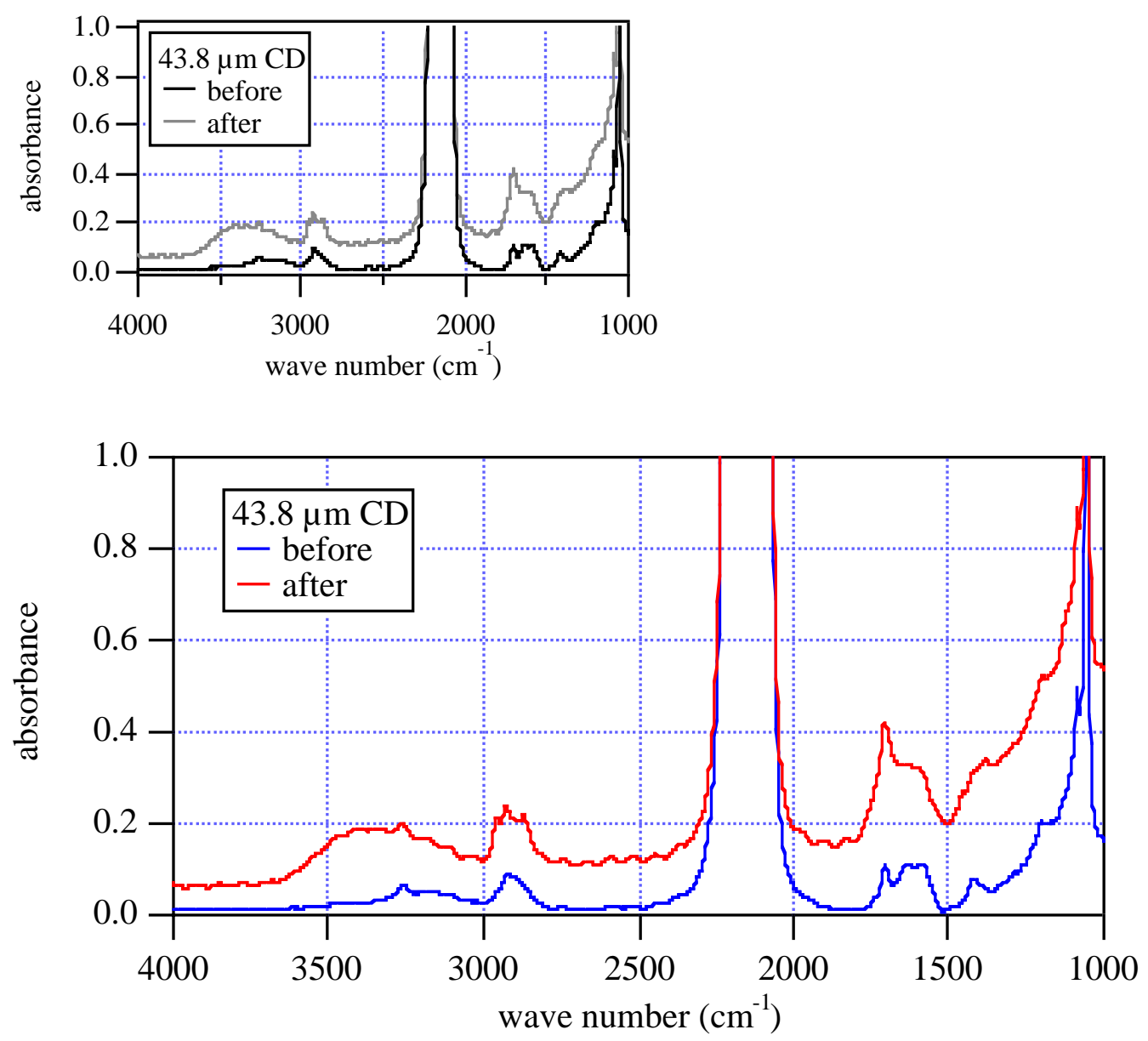
Figure 7
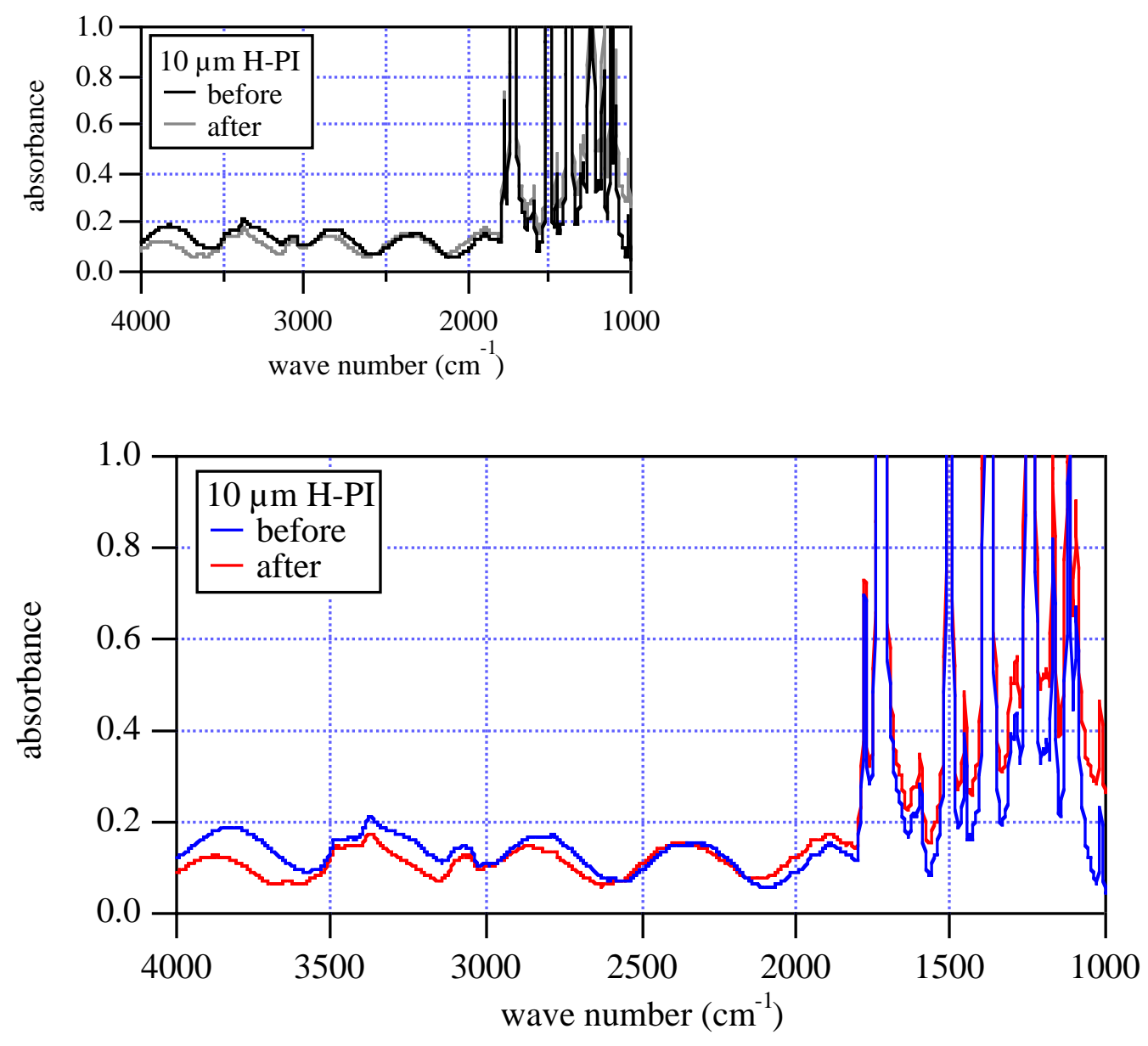

\section{References}

${ }^{1}$ ref to NIF. There are several relevant ones. I'll get them later.

2 S. A. LETTS, D. W. MYERS, AND L. A. WITT, "Ultrasmooth Plasma Polymerized Coatings for Laser Fusion Targets", J. Vac. Sci. Technol. 19, 739 (1981); must be other better ones

${ }^{3}$ S. A. Letts, M. Anthamatten, S. R. Buckley, E Fearon, A. E. H. Nissen, and R. C. Cook, "Progress toward Meeting NIF Specifications for Vapor Deposited Polyimide Ablator Coatings," Fusion Science and Technology 45, 180 (2004), and references therein.

${ }^{4}$ P.C. Souers, Hydrogen Properties for Fusion Energy; University of California Press: Berkeley 1986.

${ }^{5}$ Y.A. Merkulley and S.A. Startsev "Introduction of Tritium into Polymer Structure of Shell Targets. Isotope Exchange and Degradation of Polymer." Proc. SPIE, Vol. 4424, 120 (2001). 
${ }^{6}$ C-Y. Cha "Tritium Exchange Studies on Poly(Ethylene Terephthalate)," Polymer Let., 2, 1069 (1964).

${ }^{7}$ P.M.S. Jones and R. Gibson "The Interaction of Tritium Gas with Polyethylene," Atomic Weapons Research Establishment Report No. 0-16/63 (1963).

${ }^{8}$ E.A. Clark, K.L. Shanahan, and M.J. Pechersky "Effects of 108 Days Tritium Exposure on UHMW-PE, PTFE, and Vespel," Westinghouse Savannah River Report SRT-MTS2002-30013 (2002).

${ }^{9}$ Polyimides Fundamentals and Applications; M.K. Ghosh and K.L. Mittal, Eds.; Marcel Dekker: New York (1996).

10 same ref to formation of $\mathrm{CH}, \mathrm{CD}$

11 P. S. Ebey, et al., "title," this issue.

${ }^{12}$ W.S. Li, Z.X. Shen, J.Z. Zheng, and S.H. Tang "FTIR Study of the Imidization Process of Photosensitive Polyimide PMDA/ODA," Appl. Spectrosc. 52, 985 (1998). C.A. Pryde "IR Studies of Polyimides. I. Effects of Chemical and Physical Changes During Curing," J. Poly. Sci. Part A: Polym. Chem. 27, 711 (1989).

13 Marwin K. Kemp, Physical Chemistry. Marcel Dekker, New York, 1979, pp 471-4 